Bond University ePublications@bond

Sports Law eJournal

Faculty of Law

8-23-2016

Securing Health and Safety at Major Sporting Events

Eric Windholz

Monash University, Australia

Follow this and additional works at: http://epublications.bond.edu.au/slej

Cart of the Law Commons

Recommended Citation

Eric Windholz. (2016) "Securing Health and Safety at Major Sporting Events" Sports Law eJournal,, : ISSN 1836-1129.

http://epublications.bond.edu.au/slej/31

This Journal Article is brought to you by the Faculty of Law at ePublications@bond. It has been accepted for inclusion in Sports Law eJournal by an authorized administrator of ePublications@bond. For more information, please contact Bond University's Repository Coordinator. 


\title{
Securing Health and Safety at Major Sporting Events
}

\begin{abstract}
This article examines the duties and responsibilities owed by persons involved with organising and staging major sporting events under Australian workplace health and safety (WHS) laws. While WHS laws focus primarily on the health and safety of workers, they also have a very broad public safety component. This examination reveals multiple actors involved with major sporting events owe broad, concurrent, overlapping and non-delegable WHS duties. The duties appear to impose onerous obligations on event organisers to ensure the safety of work undertaken by expert contractors they engage. On closer examination, however, the duties form part of a larger legislative scheme that allocates risk management responsibilities amongst persons involved with major sporting events.
\end{abstract}

\section{Keywords}

WHS law, risk management, duties, responsibilities, Olympic, Commonwealth, games

\section{Disciplines}

Law 


\title{
SECURING HEALTH AND SAFETY AT MAJOR SPORTING EVENTS
}

\author{
ERIC WINDHOLZ*
}

\begin{abstract}
This article examines the duties and responsibilities owed by persons involved with organising and staging major sporting events under Australian workplace health and safety (WHS) laws. While WHS laws focus primarily on the health and safety of workers, they also have a very broad public safety component. This examination reveals multiple actors involved with major sporting events owe broad, concurrent, overlapping and non-delegable WHS duties. The duties appear to impose onerous obligations on event organisers to ensure the safety of work undertaken by expert contractors they engage. On closer examination, however, the duties form part of a larger legislative scheme that allocates risk management responsibilities amongst persons involved with major sporting events.
\end{abstract}

\section{INTRODUCTION}

Major sporting events come in a variety of forms. Some are held in permanent, purpose built venues such as the Melbourne Cricket Ground or the Gabba in Brisbane. Others such as the Melbourne Formula One Grand Prix and Castrol Gold Coast 600 are held in public spaces adapted for the purpose. Some like the National Rugby League and Australian Football League Grand Finals are held on one day and at one venue; others are held over many days at one venue (eg, Test Cricket); and others still over many days and at many venues (eg, Olympic and Commonwealth Games). The success of these events is generally measured in terms of the spectacle, attendance and television ratings, and economic benefit. Another important (albeit less appreciated) measure of success is participant, patron and public health and safety.

Many actors involved with a major sporting event contribute to its safe staging. They include event organisers, those who design, construct and manage the venues at which the event is held, designers, manufacturers and suppliers of event plant and equipment, and the army of workers who do everything from man the gates, feed the crowds and clean up after them. This paper examines the duties and responsibilities owed by these persons under Australian workplace health and safety (WHS) laws. The application of WHS law to major sporting events does not appear to have received much attention in academic circles. Rather, academic discourse on health and safety issues at major sporting events tends to focus on public health and disease management, ${ }^{1}$ and terrorism and security risks. ${ }^{2}$ Yet as will be seen, WHS laws apply to nearly every aspect of the organisation and staging of a major sporting event. ${ }^{3}$

The first part of this article overviews the actors and activities involved in organising and staging a major sporting event using the 2018 Gold Coast Commonwealth Games as its case study. The size and complexity of the Commonwealth Games provides a rich factual matrix from which to examine the application of WHS laws. This overview reveals that hosting the Commonwealth Games is a team exercise involving multiple actors with overlapping roles and responsibilities. The second part of the article then identifies the WHS duties owed by these actors. This examination reveals multiple actors owing concurrent and overlapping duties with respect to the same activities. The third part of the paper then examines how WHS law deals with multiple overlapping duties with a particular focus on the application of the duties to the relationship between event organisers and contractors they retain. On first examination, these duties appear to impose onerous duties on event organisers to ensure the safety of work undertaken by the contractors they engage. On closer examination, however, the duties form part of a larger legislative scheme that establishes a pragmatic framework that facilitates the effective allocation of risk

* Senior Lecturer and Associate, Monash Centre for Commercial Law and Regulatory Studies, Monash University.

1 See, eg, K E Enock and J Jacobs, 'The Olympic and Paralympic Games 2012: Literature review of the logistical planning and operational challenges for public health' (2008) 122 Public Health 1229-1238.

2 See, eg, Richard Giulianotti, 'Security Governance and Sport Mega-events: Towards an Interdisciplinary Research Agenda' (2010) 34 Journal of Sport and Social Issues 49-61; Kristine Toohey, 'Terrorism, Sport and Public Policy in the Risk Society' (2008) 11 Sport and Society 429-442; Richard Giulianotti and Franceso Klauser, 'Sport Management and Terrorism: A Critical Analysis' (2012) 47 International Review for the Sociology of Sport 307-323.

3 While this article contributes to filling the gap in the academic literature concerning the application of WHS laws to major sporting events, its analysis is limited to Australian jurisdictions. Similar issues are likely to arise in other countries hosting major sporting events, although the exact nature and application of the laws will differ. This makes the topic a potentially fruitful area of future research for persons interested in WHS, sports law and sports management. 
management responsibilities amongst persons involved with major sporting events. The paper then concludes with some practical advice for event organisers on managing contractors consistent with their WHS obligations.

\section{COMMONWEALTH GAMES - ACTORS AND ACTIVITIES}

Commonwealth Games are awarded to host cities by the Commonwealth Games Federation (CGF). The CGF is an associated organisation of The Commonwealth of Nations responsible for the direction and control of the Commonwealth Games. ${ }^{4}$ The terms and conditions pursuant to which the Games are awarded and must be conducted are laid down in the CGF's Constitution, Regulations and Code of Conduct, the Games Manual and the Host City Contract. ${ }^{5}$ These documents contain no express reference to WHS. The CGF also provides host cities with a detailed knowledge repository to assist with Games' organisation. The repository includes: process tools; proforma contracts and requests for proposals; sport and venue specifications and technical data; strategy and operating plans; and event guides, manuals and specifications. ${ }^{6}$

The successful bidder for the 2018 Commonwealth Games was the Australian Commonwealth Games Association (ACGA) in partnership with the Queensland Government and the City of Gold Coast. ${ }^{7}$ The Queensland Government has delegated organisation of the Games to the Gold Coast 2018 Commonwealth Games Corporation (GOLDOC). GOLDOC was established on 1 January 2012 as an independent statutory authority under the Commonwealth Games Arrangements Act 2011 (Qld). The functions of GOLDOC are to undertake and facilitate the organisation, conduct, promotion and commercial and financial management of the Commonwealth Games. GOLDOC does not do this on its own, however. Rather, it partners with several arms of the Queensland government, including: ${ }^{8}$

- the Office of Commonwealth Games Coordination (OCGC) within the Department of Tourism, Major Events, Small Business and the Commonwealth Games. The OCGC coordinates the provision of Queensland Government services required to deliver the Games, and controls the capital budget for Games venues.

- the Queensland Department of State Development (DSD) which is responsible for delivery of the Games venue and village infrastructure program, and project and contract management of individual infrastructure projects.

- the Commonwealth Games Infrastructure Authority (CGIA) (established under the Economic Development Act 2012 (Qld)) which, together with the Queensland Economic Board (a committee of senior public servants), oversees delivery of the Games capital infrastructure projects.

GOLDOC also partners with the City of Gold Coast which is responsible for delivering city operations, legacy, arts and cultural initiatives, and with the Federal Health Department's Population Health and Sports Division that coordinates Australian Government input with respect to security, immigration, customs, intellectual property, tourism and communications.

The above description of actors only gives a hint of the activities involved in hosting an event the size of the Commonwealth Games. Much more is involved. In fact, GOLDOC has organised itself around 41 functional areas. ${ }^{9}$ It suffices to focus on three areas to illustrate the breadth, depth and complexity of activities impacting participant, patron and public health and safety: infrastructure; logistics; and event day hospitality.

Hosting a Commonwealth Games involves constructing significant new infrastructure. New sporting venues need to be built, and existing ones need to be renovated. The Games village also needs to be constructed, as does transport infrastructure (roads, rail, etc). Employing the transport infrastructure to move people and goods between Games venues efficiently and safely is a major logistical exercise requiring both detailed planning and significant plant and equipment to execute. Hundreds of trains, buses, cars and other vehicles are needed to transport thousands of participants, officials and spectators; their movements need to be timetabled and communicated; and their interchanges managed and coordinated. And finally there is event day hospitality. This involves security and crowd control moving tens of thousands of people in, out and within the venues. It also

4 The Commonwealth of Nations is a voluntary association of independent sovereign states that were former British colonies or dependencies of British colonies.

Copies of these documents can be found on the CGF website - http://www.thecgf.com.

CGF, Candidate City Manual 2018 Commonwealth Games (May 2011) 6.

The Australian Commonwealth Government supported, but was not a formal signatory to, the bid.

The following information is sourced from: GOLDOC, Annual Report 2014-15 (Queensland Government, 2015) 11-12.

9 For a list of the 41 functional areas, see: Queensland Audit Office, 2018 Commonwealth Games Progress, Report 9: $2014-15$

(Queensland Audit Office, 2014) Appendix C. 
involves plant, equipment and substances (some flammable and hazardous) being used to provide patrons with food, drink and alcohol, and to clean up after them and manage their waste.

Of course, GOLDOC and its government partners do not undertake all these activities themselves. Most require technical and other expertise not held by government. The vast majority of these activities are (or will be) contracted out to a variety of mainly private organisations. Venue infrastructure, for example, is being designed and constructed by several private companies under contracts with DSD, ${ }^{10}$ and the Queensland Government has established a procurement portal through which it plans to purchase approximately $\$ 2$ billion worth of goods and services from private businesses. ${ }^{11}$ Viewed this way, the Commonwealth Games is as much an industrial and commercial conglomerate as it is a sporting event; as much a public-private partnership as it is a public event. This creates a complex web of inter-dependent actors, each of whom, to some degree, undertake activities with the potential to impact the health and safety of persons attending the event.

\section{WORKPLACE HEALTH AND SAFETY DUTIES}

In this section, we examine the WHS duties owed by these actors. The analysis is based on Queensland's Work Health and Safety Act 2011 ('WHS Act') and Victoria's Occupational Health and Safety Act 2004 ('OHS Act'). These Acts are representative of the two forms of WHS laws operating in Australia today: the WHS Act being representative of regimes that have recently harmonised their WHS laws; and the OHS Act being representative of a non-harmonised regime. ${ }^{12}$

Both the WHS Act and the OHS Act have as their object protecting workers and other persons against harm to their health, safety and welfare through the elimination or minimisation of risks arising from work. ${ }^{13}$ Both Acts seek to meet this object by imposing a series of duties on persons (or entities) whose acts or omissions are capable of giving rise to such risks of harm. The main WHS duties are summarised in Table 1.

10 For more information on venue infrastructure, see http://www.statedevelopment.qld.gov.au/index.php/component/mtree/gold-coast-2018-commonwealth-games

11 See www.gc2018.com/procurement.

12 In Australia, the Commonwealth and each State and Territory has its own WHS regulatory regime. Recent efforts to harmonise these regimes produced near identical WHS laws in all jurisdictions except Victoria and Western Australia. (For a discussion of the harmonisation process, see Eric Windholz, 'The harmonisation of Australia's occupational health and safety laws: much ado about nothing?' (2013) 26(2) Australian Journal of Labour Law 185-213).

13 OHS Act s 2 and 4; WHS Act s 3(1). 
Table 1 - Summary of Main Statutory WHS Duties

\begin{tabular}{|c|c|c|}
\hline \multirow[t]{2}{*}{ Duty-holder } & \multicolumn{2}{|l|}{ Main Statutory WHS Duties } \\
\hline & Queensland WHS Act & Victorian OHS Act \\
\hline $\begin{array}{l}\text { Persons conducting } \\
\text { a business or } \\
\text { undertaking } \\
\text { (PCBUs) / } \\
\text { Employers }^{14}\end{array}$ & $\begin{array}{l}\text { Ensure, so far as is reasonably } \\
\text { practicable, the health and safety of } \\
\text { workers engaged or caused to be } \\
\text { engaged by them, or whose work } \\
\text { activities are influenced or directed by } \\
\text { them, while the workers are at work in } \\
\text { their business or undertaking (s 19(1)) } \\
\text { Ensure, so far as is reasonably } \\
\text { practicable, that the health and safety of } \\
\text { other persons is not put at risk from } \\
\text { work carried out as part of the conduct } \\
\text { of the business or undertaking (s 19(2)) }\end{array}$ & $\begin{array}{l}\text { Provide and maintain, so far as is reasonably } \\
\text { practicable, a working environment for its } \\
\text { employees (and for independent contractors } \\
\text { engaged by it and their employees) that is safe } \\
\text { and without risks to health (s } 21(1) \text { \& (3)) } \\
\text { Ensure, so far as is reasonably practicable, } \\
\text { that persons other than its employees are not } \\
\text { exposed to risks to their health and safety } \\
\text { arising from the conduct of the employer's } \\
\text { undertaking (s } 23(1) \text { ) }\end{array}$ \\
\hline $\begin{array}{l}\text { Designers, } \\
\text { manufacturers, } \\
\text { suppliers of plant, } \\
\text { substances or } \\
\text { structures }^{15}\end{array}$ & $\begin{array}{l}\text { Ensure, so far as is reasonably } \\
\text { practicable, that plant, substances or } \\
\text { structures used at a workplace are safe } \\
\text { and without risks to health when used } \\
\text { for the purpose for which they are } \\
\text { designed, manufactured or supplied (ss } \\
\text { 22-26) }\end{array}$ & $\begin{array}{l}\text { Ensure, so far as is reasonably practicable, } \\
\text { that plant and substances used at a workplace } \\
\text { are safe and without risks to health when used } \\
\text { for the purpose for which they are designed, } \\
\text { manufactured or supplied (ss } 27-31 \text { ) }\end{array}$ \\
\hline $\begin{array}{l}\text { Managers and } \\
\text { controllers of } \\
\text { workplaces }\end{array}$ & $\begin{array}{l}\text { Ensure, so far as is reasonably } \\
\text { practicable, that the workplace, the } \\
\text { means of entering and leaving it, and } \\
\text { anything arising from it, are without } \\
\text { risks to the health and safety of any } \\
\text { person (s 20) }\end{array}$ & $\begin{array}{l}\text { Ensure, so far as is reasonably practicable, } \\
\text { that the workplace, and the means of entering } \\
\text { and leaving it, are safe and without risks to } \\
\text { health (s 26) }\end{array}$ \\
\hline $\begin{array}{l}\text { Directors and } \\
\text { officers }\end{array}$ & $\begin{array}{l}\text { Exercise due diligence (take reasonable } \\
\text { steps) to ensure company complies with } \\
\text { its WHS duties and obligations (s } 27 \text { ) }\end{array}$ & $\begin{array}{l}\text { Take reasonable care to prevent the company } \\
\text { from contravening the Act (s 144) }\end{array}$ \\
\hline $\begin{array}{l}\text { Workers / } \\
\text { Employees }\end{array}$ & $\begin{array}{l}\text { Take reasonable care that his/her acts } \\
\text { or omissions do not adversely affect the } \\
\text { health and safety of other persons (s 28) }\end{array}$ & $\begin{array}{l}\text { Take reasonable care for the health and safety } \\
\text { of persons who may be affected by their acts } \\
\text { or omissions at the workplace (s } 25(1) \text { ) }\end{array}$ \\
\hline $\begin{array}{l}\text { Other persons at } \\
\text { the workplace }\end{array}$ & $\begin{array}{l}\text { Take reasonable care that his/her acts } \\
\text { or omissions do not adversely affect the } \\
\text { health and safety of other persons (s 29) }\end{array}$ & $\begin{array}{l}\text { Not to engage in reckless conduct that places } \\
\text { another person at a workplace in danger of } \\
\text { serious injury (s 32) }\end{array}$ \\
\hline
\end{tabular}

14 The WHS Act imposes its primary duties on 'persons conducting a business or undertaking' (PCBU), which is defined to include a person conducting a business or undertaking whether alone or with others, and whether or not for profit or gain (WHS Act, s 5). The OHS Act frames the equivalent duties by reference to an 'employer', which is defined to mean a person who employs one or more persons under a contract of employment or training (OHS Act, s 5).

15 'Substance' means 'any natural or artificial substance, whether in the form of a solid, liquid, gas or vapour'; 'plant' includes any machinery, equipment, appliances, implements and tools (WHS Act, s 4, Schedule 5; OHS Act s 5). However, 'plant specifically designed for a sporting activity' is excluded from these definitions: in Queensland by virtue of being excluded from the definition of amusement devices (Work. Health and Safety Regulations 2011 (Qld), reg 5 and Schedule 19); and in Victoria by its non-inclusion in the exhaustive list of plant to which the plant regulation applies (see Occupational Health and Safety Regulations 2007 (Vic), reg 3.5.1).

16 Under the WHS Act, duties are owed by 'workers', which is defined to include employees, contractors, sub-contractors and their employees, and volunteers (WHS Act, s 7). Under the OHS Act, only 'employees' owe duties, which is defined to mean persons under a contract of employment or training (OHS Act, s 5). Volunteers therefore do not owe 'employee' OHS duties in Victoria, but would owe duties as 'other persons at the workplace' per Table 1. 
Space does not permit a detailed examination of these duties. For present purposes, it suffices to note three important features as they apply to major sporting events like the Commonwealth Games. First, the duties are owed for the benefit of workers and employees (the traditional focus of WHS laws), and for the benefit of 'other persons'. These other persons can include participants, patrons and members of the public. The public safety component of WHS laws is not always recognised, or its implications appreciated and understood.

Second, applying these duties to persons involved with organising and staging the Commonwealth Games reveals numerous duty-holders. For the purposes of this paper, these duty-holders can be classified into two broad groups whom I shall call 'principals' and 'contractors'. ${ }^{17}$ Principals are those entities for which the 2018 Gold Coast Commonwealth Games is, or forms part of, their business or undertaking. This would include the entities directly charged with delivering the Games (GOLDOC and its federal, state and local government organising partners). It also arguably includes the Games custodian and premier rule maker (the CGF), and potentially even the successful bidders for the Gold Coast Games on whose behalf the Games are being conducted (the ACGA, Queensland Government and the City of Gold Coast). ${ }^{18}$ Contractors, on the other hand, are entities engaged by the principals to undertake specific activities in support of the organisation and staging of the Games. These would include, for example, the architects and builders engaged to design and construct the Games infrastructure, venue managers and controllers, and the various companies engaged to provide security and crowd control, catering and hospitality, and cleaning and waste management services at Games venues. Contractors owe duties as PCBUs (in Queensland) and employers (in Victoria), their specific area of activity (be it construction, transport and logistics, or hospitality) being their business or undertaking with respect to which they employ people. And depending on the nature of the work they perform, they also may owe duties as designers, manufacturers and suppliers of structures, plant and equipment, or as venue managers and controllers (see Table 1).

Third, these multiple duty-holders owe duties with respect to the same activities. To illustrate, let us briefly examine the construction of Games' venues. The venues form a key component of the business or undertaking that is the Commonwealth Games. They are constructed in accordance with the CGF's specifications, are part of the organisation and conduct of the Games for which GOLDOC is primarily responsible, and is part of the Games' infrastructure program for which OCGC, DSD and CGIA have responsibilities. Then there are the architects and construction companies engaged to design and build the Games venues, and the designers, manufacturers and suppliers of plant and equipment to be installed and used within the venues. Each of these actors owes WHS duties with respect to the venues' construction and intended use. This is the case notwithstanding that each of the principals and contractors have different capacities to control the risks associated with that construction and use.

The existence of multiple duty-holders owing duties with respect to the same activities gives rise to a number of important questions. What is 'reasonably practicable' for each duty-holder in the circumstances? Is one duty limited by the existence of another duty and, if yes, which duty is limited and to what extent? Does it matter that some duty-holders have a greater capacity to control the risks than other duty-holders? It is to these questions that the paper now turns.

\section{MULTIPLE OVERLAPPING DUTIES}

To understand how WHS law deals with multiple duty holders owing duties with respect to the same activities, it is first necessary to understand the tension inherent in balancing WHS laws' protective and remedial nature with real world practicalities. WHS laws protective nature is evident in the legislative requirement that duty-holders 'ensure' the health and safety of workers and other persons. It also is evident in judicial pronouncements that courts should give WHS legislation a generous construction. For example, in Waugh v Kippen, the High Court said of Queensland factory laws (precursors to today's WHS laws):

17 There are other groups, namely directors and officers, and workers and employees. These groups are not germaine to the focus of this paper, however, and have been excluded from the analysis. For a discussion of the duties they owe, see Eric Windholz, 'Team-based Professional Sporting Competitions and Work Health and Safety Law: Defining the Boundaries of Responsibility' (2015) 43 Australian Business Law Review 303.

18 Whether the later bodies owe duties is a question of fact to be determined, in part, by reference to whether the level of management control they exercise is such that they can be said to be 'conducting' the Games. In the case of the GCF, for example, we have observed that the Games are conducted pursuant to its Constitution, Regulations, Code of Conduct, Games Manual and Host City Contract. Its role arguably is analogous to that of a franchisor. Franchisors owe duties as a PCBU under the WHS Act, and an employer under the OHS Act. It also should be noted that the Queensland definition of PCBU would capture the CGF notwithstanding it is an overseas body as it is carrying on a business or undertaking in Queensland. However, the OHS laws would catch the CGF only if it employs people (ie, is an employer). 
the court must proceed with its primary task of extracting the intention of the legislature and the fair meaning of the words by which it has expressed that intention, remembering that it is a remedial measure passed for the protection of the worker. It should not be construed so strictly as to deprive the worker of the protection which Parliament intended that he should have ... ${ }^{19}$

Consistent with the generous approach, courts have held that WHS duties are absolute in the sense that a person's knowledge of the wrongfulness of the act is not an element of an offence, there being no room for a defence of honest and reasonable mistake. ${ }^{20}$ Courts also have held (and the Queensland WHS laws make clear) that WHS duties are personal, concurrent, overlapping and non-delegable. Each duty-holder must comply with its duties notwithstanding another duty holder has the same duty. ${ }^{21}$ Duty holders also cannot contract out of their duty or transfer it to another person; ${ }^{22}$ nor can they plead as a defence that the breach was 'due to the act or default of another person'. ${ }^{23}$

At the same time, however, the duties are not without limits. WHS duties are qualified by the familiar legal concept of reasonableness (reasonably practicable; reasonable care; reasonable steps). ${ }^{24}$ Courts have emphasised that what is 'reasonably practicable' is to be determined pragmatically. As Harper J observed in Holmes v R E Spence \& Co Pty Ltd:

The Act does not require employers to ensure accidents never happen. It requires them to take such steps as are practicable to provide and maintain a safe working environment. The courts will best assist the attainment of this end by looking at the facts of each case as practical people would look at them: not with the benefit of hindsight, nor with the wisdom of Solomon, but nevertheless remembering that one of the chief responsibilities of all employers is the safety of those who work for them. ${ }^{25}$

Thus, in determining what is reasonably practicable, the courts look not just at what could have been done in the circumstances to ensure people's health and safety, but whether it was reasonable in the circumstances to have done all those things or, put another way, whether it was reasonable to have done less. ${ }^{26}$ In answering this question, the WHS Act and the OHS Act direct duty-holders to take into account and weigh up all relevant matters including: ${ }^{27}$

a) the likelihood of the hazard or risk eventuating;

b) the degree of harm that would result if the hazard or risk eventuated;

c) what the person concerned knows, or ought reasonably to know, about the hazard or risk and ways of eliminating or minimising it;

d) the availability and suitability of ways to eliminate or minimise the hazard or risk; and

19 (1986) 160 CLR 156, 164-165. See also: Stratton v Van Driel Limited (1997) 87 IR 151 where Byrne J said of the predecessor to the Victorian OHS Act: 'I approach the task of construing this statute conscious that it is social legislation intended to secure the safety and welfare of persons at work and to protect them against the risks of this ... It should, therefore, be construed generously with this object in mind' (at 155).

20 See, eg, Chugg v Pacific Dunlop Ltd (1990) 170 CLR 249, 251; R v Commercial Industrial Construction Group Pty Ltd (2006) 14 VR 321, 326 [24].

21 Stratton v Van Driel Limited (1997) 87 IR 151, 155-158; WHS Act, s 16.

22 Kondis v State Transport Authority (1984) 154 CLR 672; Kirk v Industrial Relations Commission of NSW (2010) 239 CLR 531, 552 [10]); WHS Act, ss 14 and 272.

$23 \mathrm{R} v$ Commercial Industrial Construction Group Pty Ltd (2006) 14 VR 321, 326 [24].

24 For an examination of the application of the reasonableness qualifiers (reasonably practicable; reasonable care; reasonable steps) in the context of sporting endeavours, see Windholz, 'Team-based Professional Sporting Competitions and Work Health and Safety Law', above n 17.

25 (1993) VIR 119, 123. See also WorkeCover Authority (NSW) v Techniskill-Namutoni Pty Ltd [1995] NSWIRComm 127 where Cahill Dep CJ describes the Occupational Health and Safety Act 1983 (NSW) as a 'practical document' to the applied to an industry according to its custom and industrial circumstances.

26 The case law on 'reasonably practicable' is extensive. See, eg, Edwards v National Coal Board [1949] 1 KB 704; Chugg v Pacific Dunlop Ltd (1990) 170 CLR 249; Holmes v R E Spence \& Co Pty Ltd (1992) 5 VIR 119; R v Associated Octel Limited [1994] 4 All ER 1051; Slivak v Lurgi (Australia) Pty Ltd (2001) 205 CLR 304; R v ACR Roofing Pty Ltd [2004] 11 VR 187; Reilly v Devcon Australia Pty Ltd (2008) 36 WAR 492; Kirwin v The Pilbara Infrastructure Pty Ltd [2012] WASCA 99; Baiada Poultry Pty Ltd v The Queen (2012) 246 CLR 92. It is not the purpose of this article to provide a comprehensive explanation of its nature and many nuances. For such an examination, see: Richard Johnstone, Elizabeth Bluff and Alan Clayton, Work Health and Safety Law and Policy (Lawbook Co, 3'td ed, 2012) 263-312; Elizabeth Bluff and Richard Johnstone, 'The Relationship between 'Reasonably Practicable' and Risk Management Regulation' (2005) 18 Australian Journal of Labour Law 197.

27 WHS Act s 18 and Safe Work Australia, The Meaning of 'Reasonably Practicable' (Interpretive Guideline - Model Work Health and Safety Act, 2011); OHS Act s 20 and WorkSafe Victoria, How WorkS afe applies the law in relation to Reasonably Practicable (Guideline made under Section 12 of the Occupational Health and Safety Act 2004, 2004); The reference to weighing up the factors is not contained in the OHS Act but is consistent with the case law. 
e) after assessing the extent of the risk and the available ways of eliminating or controlling it, the cost associated with the available ways of eliminating or minimising the hazard or risk, including whether the cost is grossly disproportionate to the risk. ${ }^{28}$

This list is not exhaustive of the matters to be considered in determining what is reasonably practicable in the circumstances. Other relevant matters also may be considered. One such relevant matter is 'control'. Courts consistently have held that duty-holders should not be held responsible for risks emanating from activities over which they have no control, and if their control is limited, that limitation should be taken into account when determining what is reasonably practicable for that duty holder in the circumstances. ${ }^{29}$ At the same time, however, courts have interpreted 'control' broadly to include both the legal ability to control the matter (for example, a contractual or proprietary right), as well as the practical ability to do so (for example, when the duty holder and other actors understand it to be within the duty-holder's area of responsibility to give directions with respect to the activity or matter)..$^{30}$

The tension between WHS duties' remedial and protective nature and pragmatic application is reflected in the legislative conundrum that duty-holders are to 'ensure' the health and safety of persons but only 'so far as is reasonably practicable'. It has been observed that the statutory definition of 'reasonably practicable' 'give[s] little or no guidance as to what is expected of the various [multiple overlapping] duty-holders' ${ }^{31}$ Guidance can be found, however, in a series of recent cases that have considered the principal-contractor relationship. These cases differentiate between two scenarios based on the principal's level of expertise and experience with respect to the activity being undertaken. ${ }^{32}$

\section{Scenario 1: Principal (organiser) has expertise and experience}

In some situations, principals may engage contractors to do work within the principal's broad sphere of expertise and experience. In this regard, it is interesting to observe that GOLDOC's senior management team possesses a broad range of expertise and experience, including in tourism, events and sports management, stadium operations, venue infrastructure, facilities and services, and sales and marketing. ${ }^{33}$ GOLDOC also presumably has recruited senior executives and other staff experienced with organising events of similar size and complexity, and has access to the CGF's detailed knowledge repository. Its organising partners also have some level of expertise and experience in the work being outsourced to expert contactors. These are unlikely to be the first infrastructure construction projects and contracts they are managing. In this scenario, it is incumbent upon the principals to bring this expertise and experience to bear to ensure the contractors they engage employ safe systems of work.

The depth with which the principals need to review a contractor's system of work varies with the nature and risks of the work and each contractor's own level of expertise and experience (including its safety record). In some circumstances - such as where the risks are high and/or the contractor is new or operating beyond its previously demonstrated capacities - doing what is reasonably practicable may require the principal to conduct a comparatively detailed review of the contractor's system of work to satisfy itself of its safety and, if there are deficiencies or concerns with that system, to give safety instructions to the contractor to address those concerns and deficiencies, and to follow up to ensure its instructions are being followed.

\section{Scenario 2: Principal (organiser) has no expertise and experience}

In other situations, principals may engage contractors to do work outside the principals' areas of expertise such as when they engage architects and builders to design and construct new sporting venues. In this scenario, courts have recognised that it is not reasonably practicable for principals to direct contractors in their areas of expertise,

28 The legislative text for the last factor in the two Acts differ significantly. The above text is from the WHS Act. The OHS Act simply says 'the cost of eliminating or reducing the hazard or risk'. Notwithstanding the textual differences, both Acts are likely to be applied in the same manner, the WHS Act making transparent the bias in favour of safety reflected in the cases and which the Victorian regulator has stated it will apply in its interpretation of the provision (WorkSafe Victoria, above n 27).

29 See, eg, R v Associated Octel Limited [1994] 4 All ER 1051; R v ACR Roofing Pty Ltd [2004] 11 VR 187; Slivak v Lurgi (Australia) Pty Ltd (2001) 205 CLR 304.

30 Stratton v Van Driel Ltd (1997) 87 IR 151, 157.

31 Chris Maxwell QC, Occupational Health and Safety Act Review (State of Victoria, 2004) 110 [448].

32 See, eg, Reilly v Devcon (2008) 36 WAR 492; Tobiassen v Reilly (2009) 178 IR 213; Laing O'Rourke (BMC) Pty Ltd v Kirwan [2011] WASCA 117; Kirwin v The Pilbara Infrastructure Pty Ltd [2012] WASCA 99; Baiada Poultry Pty Ltd v The Queen (2012) 246 CLR 92. For a discussion of these cases, see: Richard Johnstone, 'Engaging Expert Contractors: The Work Health and Safety Obligations of the Business or Undertaking' (2014) 27 Australian Journal of Labour Law 57; Olga Klimczak, 'Safety duties and reliance on expert contractors: The Cyclone George disaster', in G W Smith (ed), Contractors Safety Management (CRC Press, 2013) 117-141.

33 See GOLDOC, above n 7, 24-25. 
and that principals generally are not expected to review the safety of the contractors' system of work, and to monitor and enforce compliance with it. ${ }^{34}$ This is the case notwithstanding the principal might have the contractual right to do so. ${ }^{35}$ At the same time, however, courts also have made it clear that the principal cannot escape its statutory WHS responsibilities simply by outsourcing work to an expert contractor. Lord Hoffman in the House of Lords case of $\mathrm{R} v$ Associated Octel Co Ltd summed up the position well when he said that it is a -

\begin{abstract}
self-evident proposition that a person conducting his own undertaking is free to decide how he will do so. Section 3 [UK equivalent to the Queensland and Victorian primary duties] requires the employer to do so in a way which, subject to reasonable practicality, does not create risks to people's health and safety. If, therefore, the employer engages an independent contractor to do work which forms part of the conduct of the employer's undertaking, he must stipulate for whatever conditions are needed to avoid those risks and are reasonably practicable. He cannot, having omitted to do so, say that he was not in a position to exercise any control. ${ }^{36}$
\end{abstract}

Clearly, as the principal's duties are personal and non-delegable, it retains some responsibility for ensuring the safety of the work it commissions. It also is clear that discharging this duty involves something more than simply engaging an expert contractor to do the work. It is to that 'something more' that the paper now turns.

\title{
MANAGING EXPERT CONTRACTORS CONSISTENT WITH WHS DUTIES
}

A principal engaging an expert contractor to do work for it is required to do what is 'reasonably practicable' to ensure the health and safety of workers and other persons is not put at risk from that work. What is reasonably practicable in any particular situation will depend upon the facts of that situation. Guidance can be found, however, in the principles of good WHS management enshrined in WHS law and discussed in the cases. In this section, five key actions distilled from those principles are identified and briefly discussed. ${ }^{37}$ Together these actions form a framework for the effective allocation of WHS risk management responsibilities to each of the actors involved with organising and staging major sporting events in accordance with their ability to control the activities that give rise to those risks.

\section{BRINGING THE RELEVANT EXPERTISE TO BEAR: CONTRACTOR SELECTION AND MANAGEMENT}

Principals have a duty to ensure the contractors they engage are competent and have the expertise, experience and qualifications to undertake the work safely and in accordance with the law and all appropriate standards, requirements and specifications. ${ }^{38}$ In Tobiasssen $v$ Reilly, the Western Australian Court of Appeal described this responsibility in the following terms:

Where, as in this case, a task requires some expertise that the responsible person does not have, their obligations under [WHS law] to ensure the safety of others will require that person to ensure that the relevant expertise is brought to bear on the task. ${ }^{39}$

What a principal must do to ensure the 'relevant expertise is brought to bear on the task' will depend on the facts of each case and, in particular, on the nature of the work and the risks associated with it. At a minimum, it would require checking the contractor's references and safety record, obtaining assurances from the contractor that it will undertake the work safely and in accordance with all relevant laws, standards, requirements and specifications, and that it will only utilise appropriately skilled and trained professionals and tradesmen. ${ }^{40}$ With respect to more complex and risky work, it may be reasonably practicable to require the contactor to undergo a safety audit and/or to have its safety management systems ISO or AS/NZS certified. ${ }^{41}$ It also is important that these assurances are

34 Reilly v Devcon (2008) 36 WAR 492; Tobiassen v Reilly (2009) 178 IR 213; Baiada Poultry Pty Ltd v The Queen (2012) 246 CLR 92. An exception is if the principal has acquired specialist knowledge in a particular area, or has been put on notice of a particular risk, in which case it would have a duty to act on that knowledge and ensure the risk is controlled appropriately (Kirwin v The Pilbara Infrastructure Pty Ltd [2012] WASCA 99 [136]).

35 Baiada Poultry Pty Ltd v The Queen (2012) 246 CLR 92, 105-106 [32]- [33].

36 [1996] 4 All ER 846, 850-851.

37 For more information on the principles and key actions, see Johnstone, above n. 32, 75-78; and for their application to major sporting events see WorkSafe Victoria, Advice for Managing Major Events Safely (April 2006) and WorkSafe Victoria, Crowd Control at Venues and Events: A Practical Occupational Health and Safety Guide (2nd ed., January 2007).

38 Tobiassen v Reilly (2009) 178 IR 213 [61]; Kirvin v The Pilbara Infrastructure Pty Ltd [2012] WASCA 99 [102], [155], [180].

39 Tobiassen $v$ Reilly (2009) 178 IR 213, 227 [61]. See also: Kirwin v The Pilbara Infrastructure Pty Ltd [2012] WASCA 99 [102].

40 Kirwin $v$ The Pilbara Infrastructure Pty Ltd [2012] WASCA 99 [108], [155], [180].

41 ISO 45001 - Occupational Health and Safety Management Systems; AS/NZS 4801 Occupational Health and Safety Management Systems. 
incorporated into the contract, and that mechanisms are put in place to monitor the contractor's compliance with its contractual and WHS obligations by, for example, requiring periodic audits of its safety to be conducted and reports furnished. Johnstone summarised this requirement well when he said:

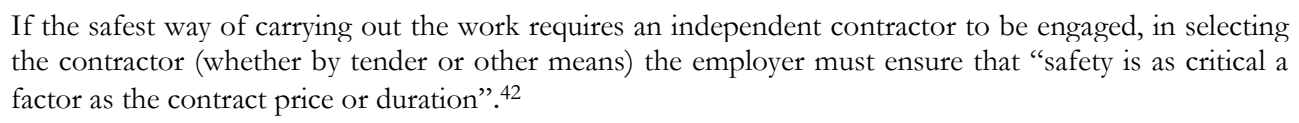

\section{WHS RISK MANAGEMENT SYSTEMS}

Risk management is central to protecting health and safety. Although WHS legislation does not mandate a formal risk management process in all situations, courts consistently have held that 'reasonably practicable' nevertheless requires duty holders to undertake the key steps of such a process, namely - hazard identification, risk assessment, identification and implementation of control measures to eliminate or minimise those risks, and monitoring and enforcement of those control measures. ${ }^{43}$ The risk management system's level of sophistication should match the complexity of the activities being undertaken, and the risks involved in them. In the case of a major sorting event, this calls for the development of a proactive, systematic and robust WHS risk management system. It is beyond the scope of this paper to attempt to prescribe in detail the specifications of such a WHS risk management system. The detail of these systems will vary according to the nature of the sporting event. Suffice to say, such a system should be carefully designed and properly resourced, its implementation diligently monitored, and any instances of non-compliance addressed promptly and decisively. Importantly, the cases emphasise that establishing paper systems is not sufficient, and that active supervision and enforcement of the system to ensure compliance with safety duties is required. ${ }^{44}$

\section{CONSULTATION AND COORDINATION}

The application of WHS duties enlivens a number of consultation, representation and participation provisions. Duty holders must consult, cooperate and coordinate their activities with other duty holders having a duty in relation to the same matter, ${ }^{45}$ and give workers/employees the ability to participate in decisions concerning their health and safety. ${ }^{46}$ In the case of the Gold Coast Commonwealth Games, this would require GOLDOC and its organising partners to work collaboratively with each other, with the expert contractors they retain, and with other relevant duty holders, to develop a holistic, integrated and coordinated WHS risk management system that includes all event risks, including those emanating from work being undertaken by contractors. ${ }^{47}$ The system should clearly identify interdependences amongst the various actors involved in WHS risk management, and provide clear mechanisms for the management of risks for which more than one actor has responsibility.

\section{ACQUIRE KNOWLEDGE RELEVANT TO REQUIRED TASKS}

Courts have interpreted 'reasonably practicable' as imposing an objective standard. ${ }^{48}$ The 'state of knowledge' against which the principal's actions is to be assessed 'is that possessed by persons engaged generally in the relevant field of activity and not merely the actual knowledge in fact possessed by a specific employer in the particular circumstances. ${ }^{49}$ This imposes an obligation on the principal to acquire the level of knowledge possessed by 'persons engaged generally in the relevant field of activity'.

This raises the question: what is principal's 'relevant field of activity'? In the case of GOLDOC, it clearly would encompass developing the infrastructure needed to stage a major sporting event; and in the case of DSD and CGIA, it would include oversighting and managing the delivery of that infrastructure. But in either case, would

42 Johnstone, above n 32, 77 citing Central Cranes Ltd v Ministry of Business, Innovation and Employment [1997] 3 NZLR 694.

43 Bluff and Johnstone, above n 26, 295 [4.435] and the cases cited therein.

44 See, eg, Inspector Kumar v Ritchie [2006] NSWIRComm 323; Work.Cover Authority (NSW) (Inspector Mansell) v Daly Smith Corporation (Aust) Pty Ltd and Smith [2004] NSWIRComm 349.

45 This duty is express in s 46 of the WHS Act which provides that '[i] $\mathrm{f}$ more than one person has a duty in relation to the same matter under this Act, each person with the duty must, so far as is reasonably practicable, consult, co-operate and co-ordinate activities with all other persons who have a duty in relation to the same matter.' While no such provision exists in the OHS Act, the importance of persons with concurrent and overlapping WHS duties consulting, cooperating and coordinating with each other 'is clearly recognised in decided OHS cases across the jurisdictions' (Commonwealth of Australia, National Review into Model Occupational Health and Safety Laws: First Report to the Workplace Relations Ministers' Council, (Australian Government, 2008) 19 [4.10]).

46 WHS Act, ss 47-49, 60-64, 75-79; OHS Act, ss 35-36, 54-71, 72.

47 For a more detailed discussion of the application of the consultation, representation and participation provisions to the principal-contractor relationship, see Olga Klimczak, 'Bridging the safety gap: Engaging specialist contractors and the duty to consult, coordinate and cooperate', in G W Smith (ed), Contractors Safety Management (CRC Press, 2013) 29-57.

48 Edwards v National Coal Board [1949] 1 KB 704, 712.

49 Laing O'Rourke (BMC) Pty Ltd v Kirwan [2011] WASCA 117 [33]. 
their 'relevant field of activity' extend to the actual construction of that infrastructure? In the cases of Reilly $v$ Devcon, Tobiassen $v$ Reilly and Kirwin $v$ The Pilbara Infrastructure Pty Ltd, the courts said it would not, and that principals do not have to acquire technical expertise to supervise expert contractors they retain to do work outside their (the principal's) area of expertise. ${ }^{50}$

Thus, in the first scenario discussed above - a principal contracting within its own field of expertise and experience - the principal is expected to have (or to have acquired) knowledge of what constitutes a safe system of work within that field, and the expertise to review and supervise the contractors system against that standard, and to take corrective action if necessary. However, in the second scenario - a principal contracting in an area about which it has no expertise or experience - there is no obligation upon it to acquire technical expertise in the contractor's field of activity. However, the principal would be expected to have (or to have acquired) the knowledge and expertise to be able to satisfy itself that the contractor has the systems, experience, expertise and qualifications to perform the work safely. In many situations, this would require the principal having the knowledge, skills and expertise to be able to compare and contrast prospective contractors' safety reports, audits and/or certifications (which might be the case in a competitive tender situation), as well as periodic safety reports and audits from contractors to whom the work is awarded. This would require the principal to have (or to have acquired) a level of WHS expertise (as opposed to technical expertise in the contractor's field of activity).

\section{ENGAGE WITH WHS REGULATORS}

Each state's WHS authority is the lead government regulator responsible for ensuring event related activities are conducted safely and without risks to health. Elsewhere I have observed that WHS regulators can be reluctant to investigate incidents involving professional sportspersons. ${ }^{51}$ WHS regulators are unlikely to display the same level of reticence with respect to the organisation and staging of major sporting events such as the Games, however. As noted earlier, the Games (and major sporting events generally) are significant industrial and commercial concerns. Many of the activities undertaken in their organisation and staging are high risk. These include construction, transport and hospitality. These activities are likely to be targeted by WHS regulators independent of their association with a major sporting event. ${ }^{52}$ However, combine these high risk activities with an event that attracts large numbers of the public, significant media attention, and which is politically important and sensitive, and one has an environment that encourages WHS regulators to be rigorous and exacting in their inspection and other regulatory activities.

It is important, therefore, for event organisers to proactively engage the relevant WHS regulator with the view to developing a constructive relationship with it. WHS regulators are an excellent source of advice on identifying WHS risks, putting appropriate control measures in place, and developing holistic, systematic and robust risk management systems of the type the courts have held are pivotal to the effective discharge of WHS duties. Moreover, the WHS regulator can offer event organisers strategic direction and support to coordinate other regulators whose mandate touches on event related health and safety issues (e.g., transport safety regulators, health departments and local government authorities). The United Kingdom's Health and Safety Executive's intervention strategy for the 2014 Glasgow Commonwealth Games is illustrative of this approach. ${ }^{53}$

50 Reilly v Devcon (2008) 36 WAR 492 [60]-[69]; Tobiassen v Reilly (2009) 178 IR 213, 227 [62]; Kirvin v The Pilbara Infrastructure Pty Ltd [2012] WASCA 99 [98]-[101]. Johnstone argues that this approach significantly undermines the principle of nontransferability of general WHS duties (Johnstone, above n 32, 84). However, to have held otherwise would have created the 'pythonesque' and burdensome result that a principal contracting out work because it does not possess expertise in an area, is then required to seek out and acquire a level of expertise in that very area in order to supervise the work it is contracting out because it had no expertise in that area in the first place.

51 Eric Windholz, 'Professional sport, work health and safety law and reluctant regulators' (2015) Sports Law eJournal ISSN 1836-1129 http://epublications.bond.edu.au/slej/28/.

52 WHS regulators do not have the resources to inspect all workplaces, and have to prioritise their limited resources among competing demands. The prioritisation process employed by WHS regulators is enshrined in their compliance and enforcement policies. These policies generally divide regulatory interventions into two categories: 'responsive' and 'targeted'. Responsive interventions take place in response to incidents reported by, or complaints received from, duty holders, workers, unions, members of the public or the media. Targeted interventions focus on industries, occupations, hazards and/or demographics identified by regulators as part of their strategic planning. Targeted areas generally are either high risk (measured by reference to the volume, severity and/or incidence of workplace injuries), or represent a vulnerable section of the community (eg, young workers; migrants). All WHS regulators have agreed a National Compliance and Enforcement Policy upon which each jurisdiction's policy is based (Safe Work Australia, National Compliance and Enforcement Policy (Safe Work Australia, 2011) available at <http://www.safeworkaustralia.gov.au/sites/swa/model-whs-laws/ncep/pages/ncep>).

53 Health and Safety Executive, Commonwealth Games 2014: Health and safety intervention strategy from summer 2013 onwards, available at $<$ http://www.hse.gov.uk/aboutus/glasgow-2014-commonwealth-games/assets/docs/intervention$\underline{\text { strategy.pdf }>\text {. }}$ 


\section{CONCLUSION}

Safely staging a major sporting event involves numerous actors, each with its particular role, and each reliant to some extent for the proper performance of that role, on other actors properly performing their roles and responsibilities. WHS laws address these symbiotic relationships by first imposing concurrent, overlapping and non-delegable WHS duties on nearly every actor involved with organising and staging the event, and then requiring the holders of these concurrent and overlapping duties to cooperate with each other to ensure their activities are undertaken safely and without risks to health. Through this combination of legislative provisions, event organisers are encouraged to work with all actors involved with the event to develop a framework that facilitates the effective allocation of risk management responsibilities amongst the various actors in accordance with each actor's ability to control the activities that give rise to those risks. 